\title{
P01-018 - An earliest diagnosis of FMF
}

\author{
N Aktay Ayaz, E Aldemir, G Keskindemirci, C Aydogmus, G Aydogan, S Kavuncuoglu \\ From 7th Congress of International Society of Systemic Auto-Inflammatory Diseases (ISSAID) \\ Lausanne, Switerland. 22-26 May 2013
}

\section{Introduction}

Familial Mediterranean fever (FMF) is an autosomal recessive disease, mainly affecting Jews, Armenians, Turks, Arabs and other groups living around Mediterranean basin. Major symptoms of disease are recurrent periodic fever accompanied by serositis. The disease is usually diagnosed at ages less than 20 years. Onset of the disease at older age can rarely occur. Symptoms related to FMF are noted when children become more verbal, usually after 2 years of age. Mutation analysis supports diagnostic evaluation.

\section{Case report}

Here, we are reporting the youngest FMF patient, that were internalized after birth as sepsis. Physicians were unable to discharge her from the hospital due to high acute phase response, that was dedicated to meningitis, urinary tract infection, sepsis and so on. Her metabolic screenings were done and were found to be negative. She was consulted to pediatric rheumatology for the high acute phase response and fever. With a detailed history and evaluation, it was learned that her mother had recurrent swelling of her ankle joints. Mutation analysis was performed and two homozygous mutations (M694V andR202Q) were identified. She was diagnosed as FMF at 3 months of age and colchicine was started with a dose of $0.25 \mathrm{mg} /$ day. She responded to colchicine both clinically and in laboratory basis. Her uncontrolled acute phase response declined gradually.

\section{Discussion}

This case was reported to point out the importance of early remembrance of possible autoinflammatory diseases even at very early ages especially at endemic countries.

\section{Disclosure of interest}

None declared.

$$
\text { Pediatric Rheumatology, Istanbul Kanuni Sultan Suleyman Education and }
$$$$
\text { Research Hospital, Istanbul, Turkey }
$$

C 2013 Ayaz et al; licensee BioMed Central Ltd. This is an Open Access article distributed under the terms of the Creative Commons Attribution License (http://creativecommons.org/licenses/by/2.0), which permits unrestricted use, distribution, and reproduction in any medium, provided the original work is properly cited.
Published: 8 November 2013

\section{References} Berkun Yackov: Familial Mediterranean Fever in the First Two Years of Life: A Unique Phenotype of Disease in Evolution. The Journal of Pediatrics 2010, 156(6):985-9.

2. Tunca M, Akar S, Onen F, Ozdogan H, Kasapcopur, Yalcınkaya F, et al: Familial Mediterranean Fever (FMF) in Turkey: results of a nationwide multicenter study. Medicine 2005, 84(1):1-11.

3. Yalcinkaya F, Ozcakar ZB, Tanyildiz M, Elhan AH: Familial Mediterranean Fever in Small Children in Turkey. Clin Exp Rheumatol 2011, 29(4 Suppl 67): $587-90$.

doi:10.1186/1546-0096-11-S1-A22

Cite this article as: Ayaz et al:: P01-018 - An earliest diagnosis of FMF. Pediatric Rheumatology 2013 11(Suppl 1):A22.

Submit your next manuscript to BioMed Central and take full advantage of:

- Convenient online submission

- Thorough peer review

- No space constraints or color figure charges

- Immediate publication on acceptance

- Inclusion in PubMed, CAS, Scopus and Google Scholar

- Research which is freely available for redistribution
1. Padeh Shai, Livneh Avi, Pras Elon, Shinar Yael, Lidar Merav, Feld Olga, 